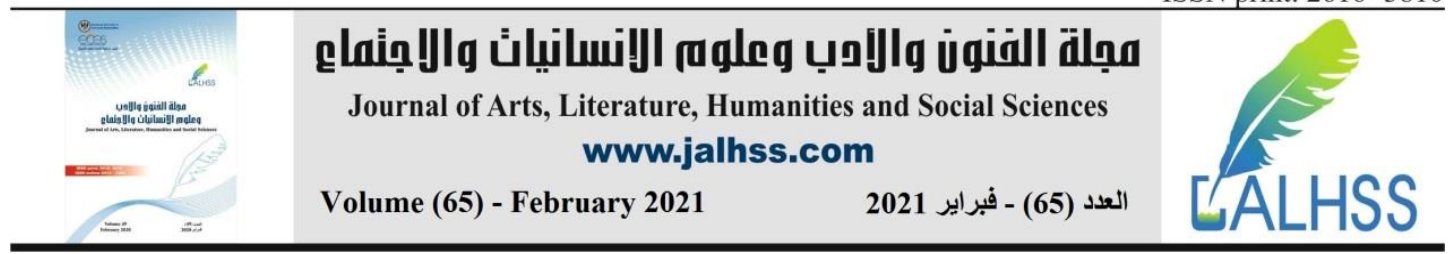

\title{
The Training Needs of Educational Leaders in Jordanian Private Universities (An Empirical Study)
}

\author{
Dr. Hatem Rateb Ameen Aljbour \\ Assistant professor \\ Online lecturer at the Islamic University of Minnesota \\ The educational administration department \\ The educational sciences faculty \\ Email: aljbourhatem@yahoo.com
}

\begin{abstract}
The present study aimed to explore the training needs of educational leaders in Jordanian private universities from their perspective. The researcher adopted a descriptive analytical approach. He employed a questionnaire and used a program called (the SPSS program) for analysing data. The population is represented in all the educational leaders in Jordanian private universities. The researcher passed 120 questionnaire forms through email to male and female heads of departments, deputies of heads of department, faculty deans, and deputies of faculty deans. However, 112 forms were retrieved and considered valid for analysis. SPSS was used. The researcher found that there is a great need for meeting the targeted administrative, technical and social training needs and IT-related training needs of the educational leaders in Jordanian private universities. The researcher recommends conducting researcher to explore the training needs of educational leaders in various types of educational institutions.
\end{abstract}

Keywords: educational leaders, private universities, Jordanian, empirical study. 


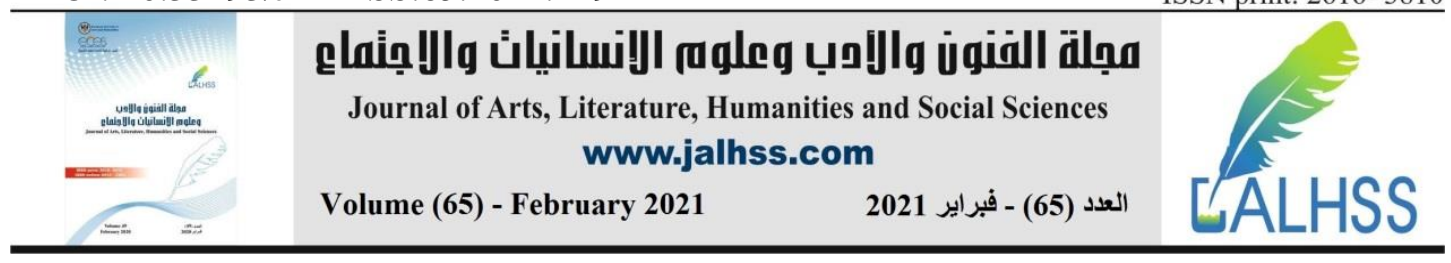

\section{Introduction}

Several scholars defined educational leadership. For instance, Hoy and Miskel (2008) defines educational leadership as the intentional influence over other people in the aim of structuring and managing relationships and activities in an organisation or group (p.419). As for Pashiardis (2004), he defines educational leadership as the act of performing behaviour in the aim of influencing others and stimulating them to do specific behaviours (p. 209). Educational leadership may be also defined as collaborating with others in a team, setting common organizational goals, developing a work strategy and motivating others to work to achieve such goals (Hallinger \& Snidvongs, 2008).

Since the beginning of this millennium, educational institutions in general and universities in particular have been facing much challenges (Salazar, 2007). In the light of such challenges, the significance of the role of educational leaders has become more evident. For instance, educational leaders affect the extent of success achieved by the institution (Glover and Law, 1996). They play a significant role in making educational reforms, meeting the diverse needs of students' and the expectations of parents and teachers (Walker and Carr-Stewart, 2006). They need to develop multidimensional strategies for developing the educators who lack knowledge and skills (Terry, 1999)

They play a major role in supporting the process of making changes and improving the quality of the delivered education. They play a significant role in improving the organizational performance. In fact, the significance of the role of educational leaders in arises from the significance of their duties. Such duties include: engaging in quality management, writing reports and staff training. They include: managing financial and human resources, and public relations efficiently and establishing partnerships. They include managing and supervising the daily operations (Pashiardis and Brauckmann, 2009).

In addition, educational leaders play a significant role in improving students' achievement. They need to deal with students from various socio-economic backgrounds efficiently. They must address the problems and issues related to educational policies, and curricula and implement educational policies efficiently (Ibrahim, 2011). Due to the significance of the role of educational leaders, their training needs must be met. They can be met through professional development courses (Al-Omari, 2019).

Educational leader must be developed professionally in an ongoing manner. Developing educational leaders professionally shall enable them to handle the $21 \mathrm{st}$ century challenges efficiently. It shall contribute to expanding their knowledge and improving their skills (Brauckmann, 2008). However, professional development requires identifying the professional development and training needs of the targeted people. That's because people can't learn and acquire skills without realizing the things they needs to learn and the skills they lack. (Mathibe, 2007)

However, professional development courses aim at developing various competencies and skills of educational leaders. For instance, they aim at developing the skills 


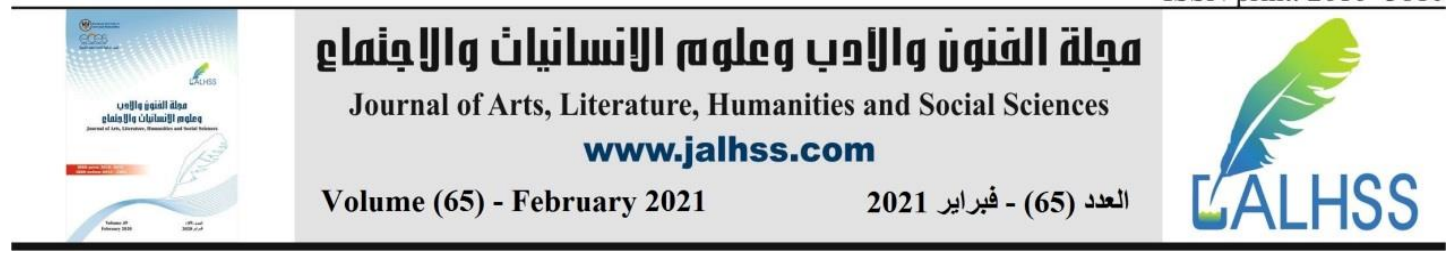

needed for developing visions, motivating, evaluating and monitoring others, creating interpersonal relationships, and managing performance and leadership skills (Mathibe, 2007). They aim at developing the competencies and skills related to educational technologies. They aim at expanding the leaders' knowledge about the social, legal, and ethical issues associated with using educational technologies. They aim at enabling leaders to create learning communities and develop, and implement, policies related to using educational technologies (Allen, 2003).

The most prevalent form of professional development is training. The training process involves skill demonstration, worksheets, presentations, and direct instruction. It aims at providing leaders with skills, values, knowledge and attitudes (Mathibe, 2007). Professional development courses contribute to developing the educational leaders' staff and resources management, communication, policy making, learning and teaching skills and skills related to quality assurance and accountability ( $\mathrm{Ng}, 2013)$. In this regard, the researcher of this study believes that providing professional courses to educational leaders shall contribute to the developing the quality of education and improving the educational system and policies. However, he believes that the training needs of educational leaders must be identified before planning for such courses. Hence, he aimed to explore the training needs of educational leaders in Jordanian private universities from their perspective.

\section{Objective:}

This study aimed to explore the training needs of educational leaders in Jordanian private universities from their perspective.

\section{Question:}

This study aimed to answer this question:

What are the training needs of educational leaders in Jordanian private universities from their perspective?

\section{The Study's Significance:}

As far as the researcher knows, this study is the first study that aimed to explore the training needs of educational leaders in Jordanian private universities from their perspective. It provides officials at the Ministry of Higher Education and Scientific Research with knowledge about the training needs of those educational leaders. It allows those officials to develop effective policies and make effective decisions for meeting such needs. It allows those officials to develop effective programs for meeting such needs. It provides the trainers of educational leaders with knowledge about the training needs of those educational leaders. That shall contribute to meeting such needs.

\section{Limits}

This study was conducted during the first semester of the academic year (2020/2021). It targets Jordanian private universities. Thus, the sample was selected from (Al-Ahliyya Amman University, Petra University, Isra University, Philadelphia University, Al-Zaytoonah University, and Zarqa University). 


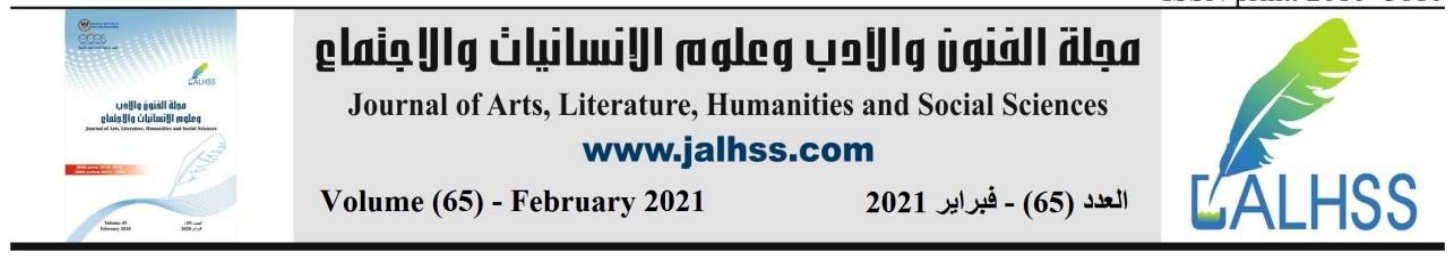

6. Definitions:

\subsection{Theoretical Definitions}

-Professional development: It refers to the process of developing employees for enabling them to do their responsibilities efficiently. It involves engaging employees in courses and activities that develop their skills and expand their knowledge. It aims at enabling employees to show the best performance (Sangster, 2000: 2).

-Training needs: They refer to the changes that must be made to one's attitudes, knowledge, skills, and performance in order for him/her to do tasks at work efficiently and effectively (Al-Zahrani, 2014)

\subsection{Operational Definitions}

-Professional development: It refers to the process of developing educational leaders in Jordanian private universities for enabling them to do their responsibilities efficiently and show the best possible performance.

-Training needs: They refer to the changes that must be made to the educational leaders' attitudes, knowledge, skills, and performance in order for those leaders to do tasks at work efficiently and effectively

\section{Theoretical framework}

There various training needs that should be met by educational leaders. In other words, educational leaders are in need for developing various competencies and skills. They are in need for developing their critical thinking skills. They are in need to have knowledge about the way of creating the about the culture of dialogue in an environment that is supportive and safe. Creating such a culture shall allow educational leaders to perceive issues from various perspectives (Kegan \& Lahey, 2000).

Educational leaders must develop their time management skills, and ability to work with others and set personal goals. They must develop their ability to manage their own stress, form teams, make decisions, and enforce Staff disciplinary procedures. They must develop their ability to develop the staff professionally and manage the stress of staff. They must develop their crisis management skills, financial management skills and, performance management skills. They must develop their ICT skills and public relation management skills (Rayner, 2002)

Educational leaders are in need for developing their human resources management skills (e.g. empowerment of staff), and financial management skills. They are in need for developing their ability to handle legal and instructional issues and curricula related issues. They are in need for developing their social and interpersonal skills and ability to develop curricula-related plans. They are in need for performing several roles efficiently. Such roles include: their roles as: mentors, models, planners, managers, facilitators, resources investigators, and visionary leaders. Educational leaders can perform all those roles efficiently through providing them with the required professional development courses ( $\mathrm{Ng}$, and Szeto, 2005)

Educational leaders must develop their ability to create and maintain positive relationships with employees. They must develop their ability to create a good workplace culture. They must realize the significance of supporting instructors and 


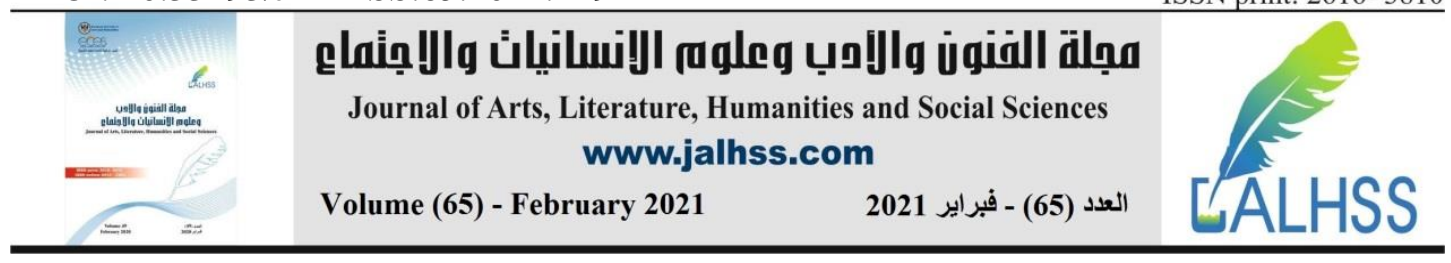

providing them with opportunities for professional and personal development (Fisher and Carlyon, 2014).

Educational leaders must develop themselves professionally, and expand their conceptual knowledge. They must develop their technical skills (Salazar, 2007). They must develop their communication skills and have knowledge about the applicable regulations and guidelines of the institution and the way of complying with them. They must serve as models for others and use methods for influencing others. Using such methods shall contribute to meeting the intended organizational and educational goals. Educational leaders must create good social relationships with employees and communicate with employees through electronic manner. In fact, using social media and other electronic means to communicate with others has become essential in the $21^{\text {st }}$ century. Educational leaders must develop their abilities to cooperate and collaborate with others for handling crises (Al-Omari, 2019).

Educational leaders must develop their creative and innovative leadership skills, and enjoying a team work spirit and promote it. They must develop their ability to detect and handle the educational problems facing the institution and be willing to share their expertise with others. They must develop their ability to use modern technologies and meet their training needs. They must develop their meeting management skills. They must show respect for different opinions, and develop their abilities to take decisions, manage time, handle educational challenges, and allocate duties (Al-Omari, 2019). They must develop their ability to develop a vision for the use of technology in the institution in the future. They must develop their ability to integrate technology in the learning environment and realize the significance of such integration (Uğur \& Koç, 2019)

\section{Empirical Studies:}

Hayat et al. (2015) explored the training needs of high school principals in Shiraz, Iran. 250 principals in Shiraz were sampled. To have data collected, researchers used a questionnaire. They analysed data through SPSS software. The researchers found that there is a great need for meeting the targeted needs of principals in all the areas. Such area. In fact, there is a great need for developing the principals' ability to organize resources, solve problems, make decisions, develop visions and missions, and implement assessment strategies. There is a great need for developing the principals' ability to promote team commitment, manage and facilitate changes, and have more knowledge about student development and learning.

Ashraah et al. (2015) explored the training needs of public school principals in Jordan. The targeted areas are planning, guidance, organization and assessment. 62 female public school principals in Jordan were sampled. 60 item-questionnaire was used. The researchers found that there is a great need for meeting the targeted needs of public school principals in Jordan in all the areas jointly and separately. Regarding the planning-related needs, there is a need for improving the principals' ability to plan semester plans, student activities, teacher schedule, and teachers-parents meetings. There is a need for improving the principals' ability to engage teachers and parents in the planning and decision making processes (Ashraah et al., 2015). 


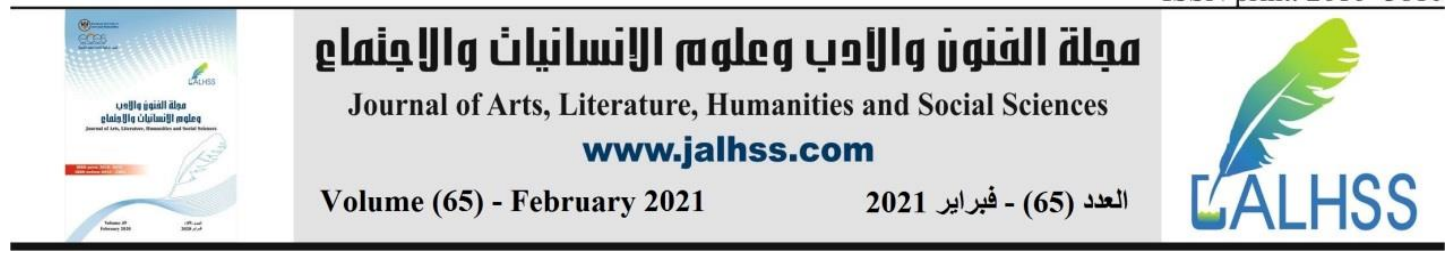

Regarding the organization -related needs, there is a need for improving the principals' ability to organize the record of employees' attendance, the records of their meetings with teachers, the records including information about the decisions of the ministry. There is a need for improving the principals' ability to delegate duties and responsibilities to teachers (Ashraah et al., 2015).

Regarding the guidance -related needs, there is a need for improving the principals' ability to guide teachers in terms of meeting the children's interests and developing children's creativity. There is a need for improving the principals' ability to guide teachers in terms of implementing the daily plans and programs, coping with the workplace environment and taking individual differences into consideration. There is a need for improving the principals' ability to guide teachers in terms of improving the teacher-parent relationships and achieving professional development (Ashraah et al., 2015).

Regarding the assessment -related needs, there is a need for improving the principals' ability to evaluate the performance of teachers and other employees. There is a need for improving the principals' ability to evaluate the way teachers cover the curriculum and write monthly reports for evaluating the work procedures at school. There is a need for improving the principals' ability to evaluate student activities and engage parents in the teacher evaluation process (Ashraah et al., 2015).

Al-Hawli (2016) explored the training needs of public school principals in Gaza. The targeted needs are administrative, social and technical needs, and needs related to IT. Analytical descriptive approach was adopted and a fifty-three questionnaire was used. Interviews were also conducted to have data collected. 391 public school principals in Gaza were sampled. The researcher found that there is a great need for meeting the targeted needs of the public school principals in Gaza $\mathrm{i}$ in all the areas jointly and separately. Regarding the administrative needs, there is a need for improving the principals' ability to hold handle emergency and write administrative reports. There is a need for improving the principals' ability to hold meetings with teachers and identify the financial and human resources that the school needs. There is a need for improving the principals' ability to develop plans for maintaining the school facilities and develop plans for the training courses of teachers. There is a need for improving the principals' leadership skills and total quality management-related skills (Al-Hawli, 2016)

Regarding the technical needs, there is a need for improving the principals' ability to analyse curricula, assess teachers, and customize the instructional programs in a manner that meets the needs of students with special needs. There is a need for improving the principals' ability to use the modern supervising methods and hold discussion with teachers after making classroom visits. There is a need for improving the principals' ability to benefit from the results of research (Al-Hawli, 2016)

Regarding the social needs, there is a need for improving the principals' ability to communicate effectively with parents and teachers, and solve the social problems existing between teachers. There is a need for improving the principals' ability to solve the social problems existing between students, and take the teachers' needs and 


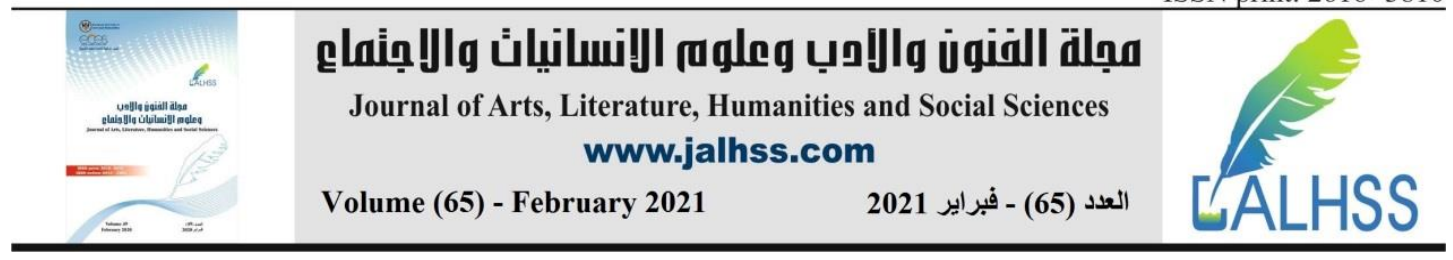

students' feelings into consideration. There is a need for improving the principals' ability to promote mutual trust between the school employees (Al-Hawli, 2016).

Regarding the IT-related needs, there is a need for improving the principals' ability to use Microsoft Word, Microsoft PowerPoint, Microsoft Excel and social media. There is a need for improving the principals' ability to use the website of the ministry and search for information through surfing the web. There is a need for improving the principals' ability to track the way of using technologies by teachers in classroom (AlHawli, 2016).

Onuma (2017) explored the training needs of public secondary principals in terms in Nigeria. The targeted needs include: needs related to supporting staff development, tracking students' achievement, supervision of classroom instruction, monitoring instructional materials. The researcher used a questionnaire. 605 public secondary principals were sampled. The researcher found that there is a great need for meeting the targeted needs of public secondary principals in terms in Nigeria.

Sharaf (2018) explored the training needs of principals in Dakahlia, Egypt in the light of the contemporary administrative thought. The targeted needs are personal skillsrelated needs, and technical, social, administrative and organizational needs. She adopted a descriptive approach and collected data through distributing questionnaire forms to the sample. 121 principals were in Dakahlia were sampled. The researcher found that there is a great need for meeting the targeted needs of the principals in Dakahlia in all the areas jointly and separately (Sharaf, 2018)

Regarding the personal skills-related needs, there is a need for improving the principals' ability to motivate employees to work for meet the school goals. There is a need for improving the principals' ability to use technology for doing tasks, show self-control during emergencies and implement modern administrative trends. There is a need for improving the principals' decision making skills and ability to develop themselves professionally, write and send e-reports, and accept others' opinions (Sharaf, 2018)

Regarding the technical needs, there is a need for improving the principals' ability to employ self-assessment, total quality management and modern supervisory methods and use planning skills. There is a need for improving the principals' ability to create a convenient learning environment, and empower employees. There is a need for improving the principals' ability to use method for developing employees' professionally (Sharaf, 2018).

Regarding the social needs, there is a need for improving the principals' ability to communicate effectively with employees and create good social relationships with teachers and parents. Regarding the administrative needs, there is a need for improving the principals' ability to manage time, conflicts, crises, and changes efficiently. Regarding the organizational needs, there is a need for expanding principals' knowledge about organizational structure, and developing principals' ability to delegate powers and utilize school resources optimally (Sharaf, 2018) 


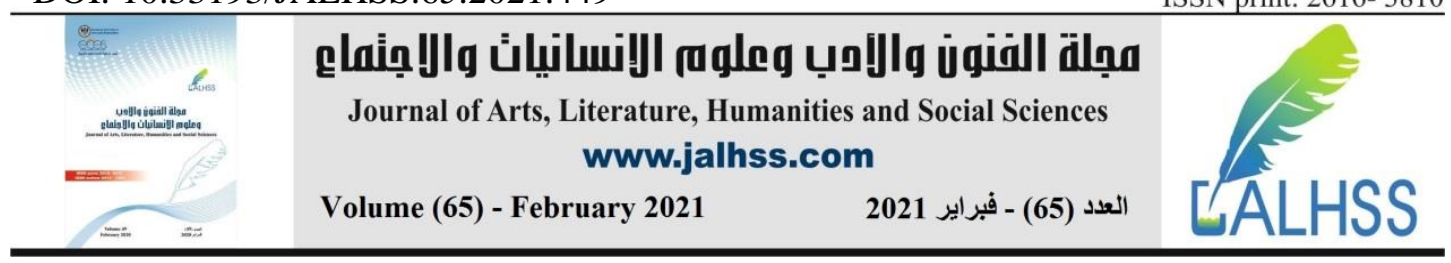

9. Methodology

9.1.Approach

Descriptive analytical approach was adopted

\subsection{Population and Sample}

The population is represented in all the educational leaders in Jordanian private universities. The researcher passed 120 questionnaire forms through email to male and female heads of departments, deputies of heads of department, faculty deans, and deputies of faculty deans. Those educational leaders were selected from: Al-Ahliyya Amman University, Petra University, Isra University, Philadelphia University, AlZaytoonah University, and Zarqa University. However, 112 forms were retrieved and considered valid for analysis. Thus, response rate is $93.33 \%$.

Table (1): Distribution of respondents in accordance with job title, gender and university

\begin{tabular}{|l|l|l|l|}
\hline Variable & Category & Frequency & Percentage \\
\hline Gender & Male & 64 & 57.14286 \\
\cline { 2 - 4 } & Female & 48 & 42.85714 \\
\hline \multirow{5}{*}{ Job position } & Heads of departments & 31 & 27.67857 \\
\cline { 2 - 4 } & Deputy head of department & 29 & 25.89286 \\
\cline { 2 - 4 } & Faculty deans & 25 & 22.32143 \\
\cline { 2 - 4 } & Deputy faculty dean & 27 & 24.10714 \\
\hline University & Al-Ahliyya Amman & 20 & \\
& University & & 17.85714 \\
\cline { 2 - 4 } & Petra University & 22 & 19.64286 \\
\cline { 2 - 4 } & Isra University & 17 & 15.17857 \\
\cline { 2 - 4 } & Philadelphia University & 15 & 13.39286 \\
\cline { 2 - 4 } & Al-Zaytoonah University & 19 & 16.96429 \\
\cline { 2 - 4 } & Zarqa University & 19 & 16.96429 \\
\hline
\end{tabular}

$\mathrm{N}=112$

\subsection{Instrument}

The researcher developed a five point Likert questionnaire. This questionnaire consists from five sections along with a cover page. It collects data about the training needs of educational leaders in Jordanian private universities. It consists from a cover page that includes information about the researcher and research goals. The first part collects data about respondents. The second part collects data about administrative training needs. It was developed based on the references of Al-Hawli (2016) and Sharaf (2018). The third part collects data about the technical training needs. It was developed based on the references of Al-Hawli (2016) and Sharaf (2018). The fourth part collects data about the social training needs. It was developed based on the reference of Al-Hawli (2016). The fifth part collects data about the IT-related training needs. It was developed based on the reference of Al-Hawli (2016).

\subsection{Validity of the Instrument}

The initial version of the questionnaire was passed to two faculty members who work at a Jordanian private university. Those faculty members hold $\mathrm{PhD}$ degree in educational leadership. They are considered experts in their field. They were asked to 


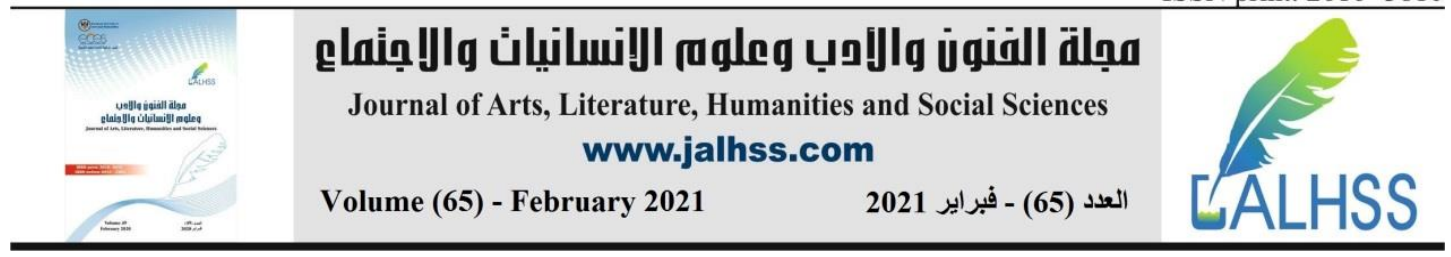

make an evaluation for the instrument. They added that the questionnaire is very clear, and capable of meeting the goals. They added that there isn't any need for making any language-related correction. However, one of the instructors recommended changing the font size. The other instructor drafted a statement and recommended adding it to the instrument. The final version was drafted. The questionnaire was passed to the members of the sample and those faculty members in Arabic language. Then, it was translated into English.

\subsection{Reliability of the Instrument}

The Cronbach alpha values are calculated for each area and listed in the table below

Table (2): Cronbach alpha values

\begin{tabular}{|l|l|l|}
\hline No. & Area & $\begin{array}{l}\text { Cronbach } \\
\text { alpha }\end{array}$ \\
\hline 1. & The administrative training needs & 0.79 \\
\hline 2. & The technical training needs & 0.83 \\
\hline 3. & The social training needs & 0.76 \\
\hline 4. & The IT-related training needs & 0.85 \\
\hline & Overall & 0.80 \\
\hline
\end{tabular}

The overall value is 0.80 . All those values indicate that the questionnaire is reliable, because they are greater than 0.70 as it's suggested by Salehi \& Farhang (2019).

\subsection{Data analysis}

To analyse the data, SPSS program was used. In addition, the researcher calculated standard deviations, percentages, frequencies and means. The criteria employed for having the means categorized are listed below:

Table (3): The criteria of classifying means

\begin{tabular}{|l|l|l|}
\hline Range & Level & Attitude \\
\hline 2.33 or less & Low & Negative \\
\hline $2.34-3.66$ & Moderate & Neutral \\
\hline 3.67 or more & High & Positive \\
\hline
\end{tabular}

*Source: Al-Amery (2020)

Regarding the five point Likert scale, it consists from five (5) rating categories that are shown below.

Table (4): The categories and scores of the five point Likert scale

\begin{tabular}{|l|l|l|l|l|l|}
\hline Category & $\begin{array}{l}\text { Strongly } \\
\text { agree }\end{array}$ & Agree & Neutral & $\begin{array}{l}\text { Disagre } \\
\mathrm{e}\end{array}$ & $\begin{array}{l}\text { Strongly } \\
\text { disagree }\end{array}$ \\
\hline The score it represents & 5 & 4 & 3 & 2 & 1 \\
\hline
\end{tabular}

\section{Discussion and Results:}

What are the training needs of educational leaders in Jordanian private universities from their perspective?

To have this question answered, the researcher calculated the means of areas and listed them in table (5). This table includes the standard deviations of the areas and levels of means. 


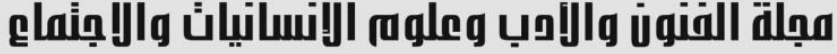 \\ Journal of Arts, Literature, Humanities and Social Sciences www.jalhss.com \\ Volume (65) - February 2021 العدد (65) - فبراير 2021}

Table (5): The means of the areas

\begin{tabular}{|c|l|l|l|l|l|}
\hline No. & Area & Mean & Std. & Level & Rank \\
\hline 1. & $\begin{array}{l}\text { The administrative training } \\
\text { needs }\end{array}$ & 4.13 & 0.42 & High & 1 \\
\hline 2. & The technical training needs & 4.07 & 0.53 & High & 4 \\
\hline 3. & The social training needs & 4.08 & 0.30 & High & 3 \\
\hline 4. & The IT-related training needs & 4.10 & 0.36 & High & 2 \\
\hline & Overall & 4.09 & 0.40 & High & \\
\hline
\end{tabular}

Based on the table above, the overall mean is 4.09. The means of the areas are within the range of (4.13-4.10). That means that there is a great need for meeting the targeted administrative, technical and social training needs and IT-related training needs of the educational leaders in Jordanian private universities. The mean of the area called the (the administrative training needs) is 4.13 which is high and ranked first. The mean of the area called the (the IT-related training needs) is 4.10 which is high and ranked second. The mean of the area called the (the social training needs) is 4.08 which is high and ranked third. The mean of the area called the (the technical training needs) is 4.07 which is high and ranked fourth.

Results and discussion about each area are presented below:

First area: The administrative training needs

Table (6): The administrative training needs of educational leaders in Jordanian private universities

\begin{tabular}{|c|c|c|c|c|c|}
\hline No. & Statement & Mean & Std. & Level & Rank \\
\hline & There is a need for: & & & & \\
\hline 1. & $\begin{array}{l}\text { developing the ability of } \\
\text { educational leaders to identify the } \\
\text { human and financial resources that } \\
\text { are needed }\end{array}$ & 2.30 & 0.54 & Low & 10 \\
\hline 2. & $\begin{array}{l}\text { developing the ability of } \\
\text { educational leaders to document } \\
\text { students-related data }\end{array}$ & 4.69 & 0.35 & High & 6 \\
\hline 3. & $\begin{array}{l}\text { developing the ability of } \\
\text { educational leaders to set plans for } \\
\text { maintaining the facilities of the } \\
\text { university }\end{array}$ & 4.80 & 0.74 & High & 3 \\
\hline 4. & $\begin{array}{l}\text { developing the total quality } \\
\text { management skills of educational } \\
\text { leaders }\end{array}$ & 4.75 & 0.67 & High & 4 \\
\hline 5. & $\begin{array}{l}\text { developing the ability of } \\
\text { educational leaders to write reports }\end{array}$ & 2.92 & 0.15 & Low & 9 \\
\hline 6. & $\begin{array}{l}\text { developing the ability of } \\
\text { educational leaders to set a vision }\end{array}$ & 4.71 & 0.22 & High & 5 \\
\hline 7. & $\begin{array}{l}\text { developing the ability of } \\
\text { educational leaders to handle } \\
\text { emergencies and crises }\end{array}$ & 4.87 & 0.23 & High & 1 \\
\hline
\end{tabular}




\begin{tabular}{|c|c|c|c|c|c|c|}
\hline \multirow{2}{*}{\multicolumn{2}{|c|}{ 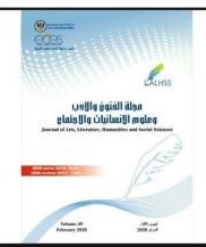 }} & \multicolumn{3}{|c|}{ 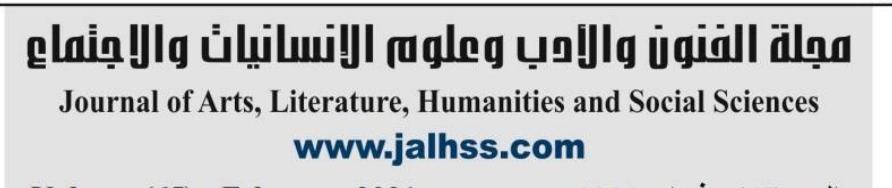 } & no & \multirow[t]{2}{*}{ HS } \\
\hline & & Volume (65) - February 2021 & \multicolumn{3}{|c|}{ العدد (65) - فبراير 2021} & \\
\hline 8. & $\begin{array}{l}\text { deve } \\
\text { educ } \\
\text { and } \\
\text { give }\end{array}$ & $\begin{array}{l}\text { oing the ability of } \\
\text { onal leaders to coordinate } \\
\text { an the training course to be } \\
\text { or instructors }\end{array}$ & 3.91 & 0.70 & High & 7 \\
\hline 9. & $\begin{array}{l}\text { deve } \\
\text { educ }\end{array}$ & $\begin{array}{l}\text { ping the ability of } \\
\text { onal leaders to manage time }\end{array}$ & 3.61 & 0.11 & Moderate & 8 \\
\hline \multirow[t]{2}{*}{10.} & $\begin{array}{l}\text { deve } \\
\text { educ } \\
\text { dutie }\end{array}$ & $\begin{array}{lcc}\text { ping } & \text { the ability of } \\
\text { onal leaders to allocate }\end{array}$ & 4.82 & 0.53 & High & 2 \\
\hline & Over & & 4.13 & 0.42 & High & \\
\hline
\end{tabular}

*Source: Al-Hawli (2016) and Sharaf (2018).

The overall mean in table (6) is 4.13. Thus, there is a great need for meeting the administrative training needs of the educational leaders in Jordanian private universities. The result in this regard is consistent with the result reached by Sharaf (2018). The mean of statement 7 is 4.87 which is high and ranked first. That means that there is a great need for developing the ability of educational leaders to handle emergencies and crises. It's necessary to develop this ability because those leaders may face emergencies and crises at any time. For instance, those leaders have been facing the COVID 19 crisis. The mean of statement 10 is 4.82 which is high and ranked second. That means that there is a great need for developing the ability of educational leaders to allocate duties. It's necessary to develop this ability to perform duties fast and assign duties based on the qualifications and skills of each employee.

The mean of statement (3) is 4.80. It's high and ranked third. Thus, there is a need for developing the ability of educational leaders to set plans for maintaining the facilities of the university. It's necessary to develop this ability to because the maintenance process must be carried in a planned and systematic manner. The mean of statement (4) is 4.75 which is high and ranked fourth. Thus, there is a need for developing the educational leaders' total quality management skills. It's necessary to develop this ability to improve the quality of the services and education provided by the university.

Second area: The technical training needs

Table (7): The technical training needs of educational leaders in Jordanian private universities

\begin{tabular}{|c|c|c|c|c|c|}
\hline No. & Statement & Mean & Std. & Level & Rank \\
\hline & There is a need for: & & & & \\
\hline 1. & $\begin{array}{l}\text { developing the ability of } \\
\text { educational leaders to analyse the } \\
\text { content of curricula }\end{array}$ & 3.56 & 0.52 & Moderate & 6 \\
\hline 2. & $\begin{array}{l}\text { Promoting knowledge among } \\
\text { educational leaders about the way } \\
\text { of developing the instructors' } \\
\text { competencies }\end{array}$ & 4.28 & 0.87 & High & 4 \\
\hline 3. & $\begin{array}{l}\text { developing the ability of } \\
\text { educational leaders to use modern }\end{array}$ & 4.73 & 0.69 & High & 1 \\
\hline
\end{tabular}




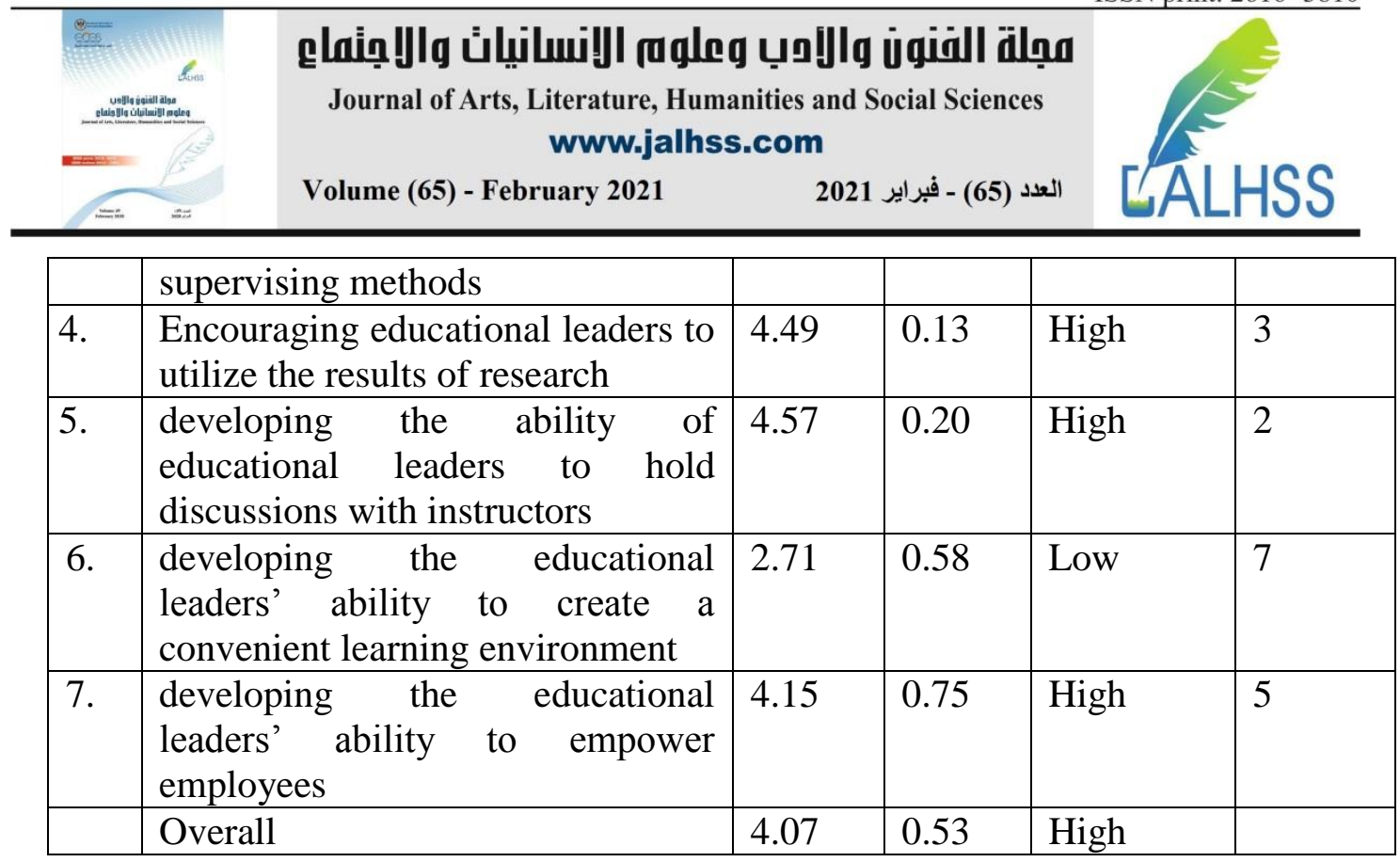

*Source: Al-Hawli (2016) and Sharaf (2018)

The overall mean in table (7) is 4.07. Thus, there is a great need for meeting the technical training needs of the educational leaders in Jordanian private universities. The result in this regard is consistent with the result reached by Al-Hawli (2016). The mean of statement 3 is 4.73 which is high and ranked first. That means that there is a great need for developing the ability of educational leaders to use modern supervising methods. It's necessary to develop this ability because the modern supervision methods are more effective than the old ones. It's necessary to develop this ability because it shall improve the outcomes of the university.

The mean of statement 5 is 4.57 which is high and ranked second. That means that there is a great need for developing the ability of educational leaders to hold discussions with instructors. It's necessary to develop this ability because it shall allow leaders to perceive issues from various perspectives. It's necessary to develop this ability because it shall allow educational leaders to expand their knowledge and expertise and identify the stand of employees on various issues. It's necessary to develop this ability because it shall allow leaders to make decisions that instructors are satisfied with

The mean of statement 4 is 4.49 which is high and ranked third. That means that there is a great need for encouraging educational leaders to utilize the results of research. Encouraging leaders to do that shall enable them to take decisions that fit with reality, attitudes and resources. The mean of statement 2 is 4.28 which is high and ranked fourth. That means that there is a great need for promoting knowledge among educational leaders about the way of developing the instructors' competencies. For instance, instructors' competencies may be developed through holding conferences, workshops, and seminars and making awards for the ones who conduct distinguished research. 


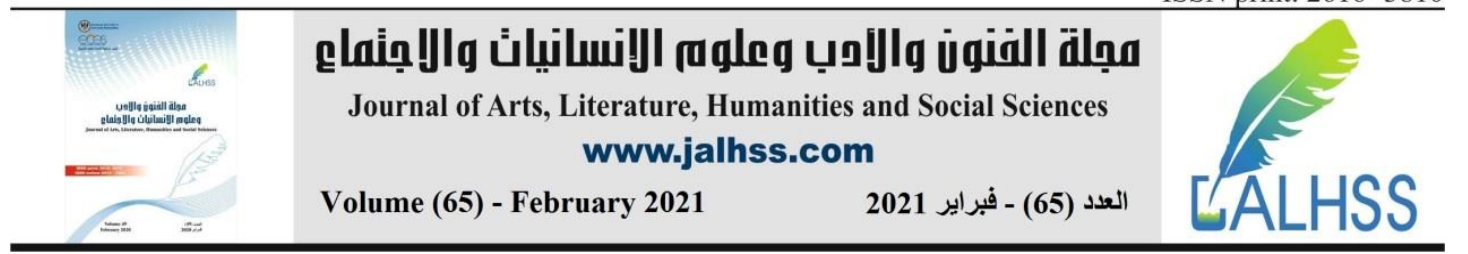

Third area: The social training needs

Table (8): The social training needs of educational leaders in Jordanian private universities

\begin{tabular}{|c|c|c|c|c|c|}
\hline No. & Statement & Mean & Std. & Level & Rank \\
\hline & There is a need for: & & & & \\
\hline 1. & $\begin{array}{l}\text { developing the ability of the } \\
\text { educational leaders to solve } \\
\text { the social problems between } \\
\text { students }\end{array}$ & 4.82 & 0.24 & High & 1 \\
\hline 2. & $\begin{array}{l}\text { developing the ability of the } \\
\text { educational leaders to solve } \\
\text { the social problems between } \\
\text { instructors }\end{array}$ & 3.96 & 0.17 & High & 6 \\
\hline 3. & $\begin{array}{l}\text { encouraging the educational } \\
\text { leaders to attend the social } \\
\text { celebrations and events of } \\
\text { employees }\end{array}$ & 2.04 & 0.36 & Low & 7 \\
\hline 4. & $\begin{array}{l}\text { encouraging the educational } \\
\text { leaders at the university to } \\
\text { take the instructors' needs and } \\
\text { interests into consideration }\end{array}$ & 4.13 & 0.42 & High & 5 \\
\hline 5. & $\begin{array}{l}\text { encouraging the educational } \\
\text { leaders to respect the opinions } \\
\text { and suggestions of instructors }\end{array}$ & 4.57 & 0.15 & High & 3 \\
\hline 6. & $\begin{array}{l}\text { developing the ability of the } \\
\text { educational leaders to } \\
\text { promote mutual trust among } \\
\text { employees }\end{array}$ & 4.42 & 0.40 & High & 4 \\
\hline \multirow[t]{2}{*}{7.} & $\begin{array}{l}\text { encouraging the educational } \\
\text { leaders to take the feelings } \\
\text { and conditions of students } \\
\text { into considerations }\end{array}$ & 4.65 & 0.38 & High & 2 \\
\hline & Overall & 4.08 & 0.30 & High & \\
\hline
\end{tabular}

*Source: Al-Hawli (2016)

The overall mean in table ( 8 ) is 4.08 . Thus, there is a great need for meeting the social training needs of the educational leaders in Jordanian private universities. The result in this regard is consistent with the result reached by Al-Hawli (2016). The mean of statement 1 is 4.82 which is high and ranked first. That means that there is a great need for developing the ability of educational leaders to solve the social problems between students. . It's necessary to develop this ability because it shall allow leaders to create a convenient learning environment that is free from tension. Resolving the social problems between students shall positively affect the students' achievement. The mean of statement 7 is 4.65 which is high and ranked second. That means that there is a great need for encouraging the educational leaders to take the feelings and 


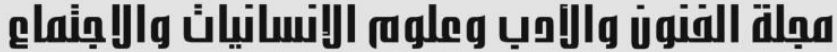 \\ Journal of Arts, Literature, Humanities and Social Sciences www.jalhss.com

conditions of students into considerations. It's necessary to encourage them to do that because it shall allow leaders to take decisions that satisfy students and improve their social bonds with students. The mean of statement 5 is 4.57 which is high and ranked third. That means that there is a great need for encouraging the educational leaders to respect the opinions and suggestions of instructors. Encouraging leaders to do that shall improve their social bonds with instructors. It shall allow leaders to promote democracy at the workplace.

Fourth area: The IT-related training needs

Table (9): The IT-related training needs of educational leaders in Jordanian private universities

\begin{tabular}{|c|c|c|c|c|c|}
\hline No. & Statement & Mean & Std. & Level & Rank \\
\hline & There is a need for:: & & & & \\
\hline 1. & $\begin{array}{l}\text { developing the ability of the } \\
\text { educational leaders to use } \\
\text { Microsoft Office programs }\end{array}$ & 2.30 & 0.15 & Low & 7 \\
\hline 2. & $\begin{array}{l}\text { developing the ability of the } \\
\text { educational leaders to use e-mails }\end{array}$ & 2.27 & 0.48 & Low & 8 \\
\hline 3. & $\begin{array}{l}\text { developing the ability of the } \\
\text { educational leaders to use social } \\
\text { media (e.g. Twitter, Facebook, and } \\
\text { etc..) }\end{array}$ & 4.79 & 0.37 & High & 2 \\
\hline 4. & $\begin{array}{l}\text { developing the ability of the } \\
\text { educational leaders to research } \\
\text { through using the web }\end{array}$ & 4.88 & 0.21 & High & 1 \\
\hline 5. & $\begin{array}{l}\text { developing the ability of the } \\
\text { educational leaders to use the e- } \\
\text { learning platform }\end{array}$ & 4.69 & 0.36 & High & 4 \\
\hline 6. & $\begin{array}{l}\text { developing the ability of the } \\
\text { educational leaders to develop, and } \\
\text { implement policies related to using } \\
\text { educational technologies }\end{array}$ & 4.65 & 0.29 & High & 5 \\
\hline 7. & $\begin{array}{l}\text { encourage leaders educational to } \\
\text { develop a vision for the use of } \\
\text { technology in the institution }\end{array}$ & 4.54 & 0.46 & High & 6 \\
\hline \multirow[t]{2}{*}{8.} & $\begin{array}{l}\text { Promote awareness about the } \\
\text { significance of integrating } \\
\text { technology in the learning } \\
\text { environment }\end{array}$ & 4.71 & 0.57 & High & 3 \\
\hline & Overall & 4.10 & 0.36 & High & \\
\hline
\end{tabular}

*Source: Al-Hawli (2016)

The overall mean in table (9) is 4.10 . Thus, there is a great need for meeting the ITrelated training needs of the educational leaders in Jordanian private universities. The result in this regard is consistent with the result reached by Al-Hawli (2016). The mean of statement 4 is 4.88 which is high and ranked first. That means that there is a 


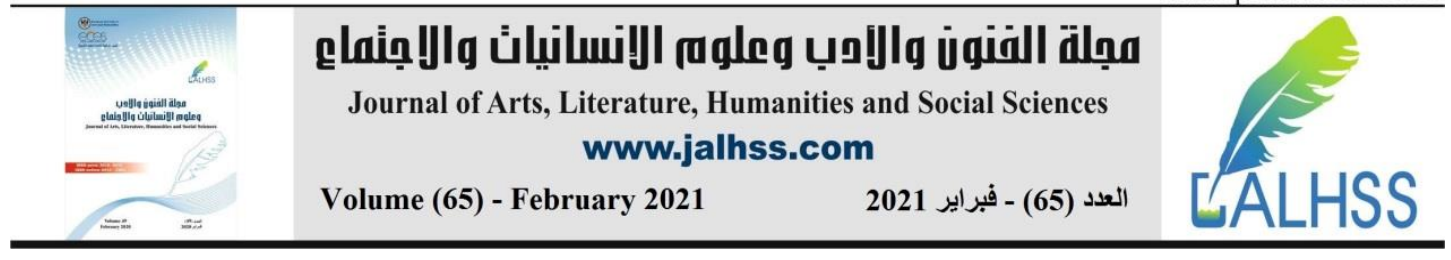

great need for developing the ability of educational leaders to research through using the web. Developing this ability shall allow educational leaders to conduct research of high quality.

The mean of statement 3 is 4.79 which is high and ranked second. That means that there is a great need for developing the ability of educational leaders to use social media (e.g. Twitter, Facebook, and etc..). It's necessary to develop this ability to identify the social celebrations and events of employees and attend them. It's necessary to develop this ability to communicate effectively with employees and track the feedback of employees and students about policies, and decisions.

The mean of statement 8 is 4.71 which is high and ranked third. That means that there is a great need for promoting awareness among leaders about the significance of integrating technology in the learning environment. Promoting such awareness shall allow leaders to encourage instructors to use educational technologies. The mean of statement 6 is 4.65 which is high and ranked fifth. That means that there is a great need for developing the ability of educational leaders to develop, and implement policies related to using educational technologies. Developing this ability shall contribute to raising the rank held by the university on world university ranking. It shall contribute to facilitating the learning process.

\section{Conclusion}

The researcher found that there is a great need for meeting the targeted administrative, technical and social training needs and IT-related training needs of the educational leaders in Jordanian private universities. Regarding the administrative training needs, there is a great need for developing the ability of educational leaders to handle emergencies and crises, set a vision, allocate duties, set plans for maintaining the facilities, and document students-related data.

Regarding the technical training needs, there is a great need for developing the ability of educational leaders to use modern supervising methods, hold discussions with instructors and empower employees. There is a great need for encouraging educational leaders to utilize the results of research. There is a great need for promoting knowledge among educational leaders about the way of developing the instructors' competencies

Regarding the social training needs, there is a great need for developing the ability of educational leaders to solve the social problems between students, and ability of take the feelings and conditions of students into considerations. There is a great need for developing the ability of educational leaders to promote mutual trust among employees and solve the social problems between instructors. There is a great need for encouraging leaders to respect the opinions and suggestions of instructors.

Regarding the IT-related training needs, there is a great need for developing the ability of educational leaders to research through using the web, use social media and the e-learning platform and develop, and implement, policies related to using educational technologies. There is a great need for developing the ability of educational leaders to develop a vision for the use of technology in the institution. 


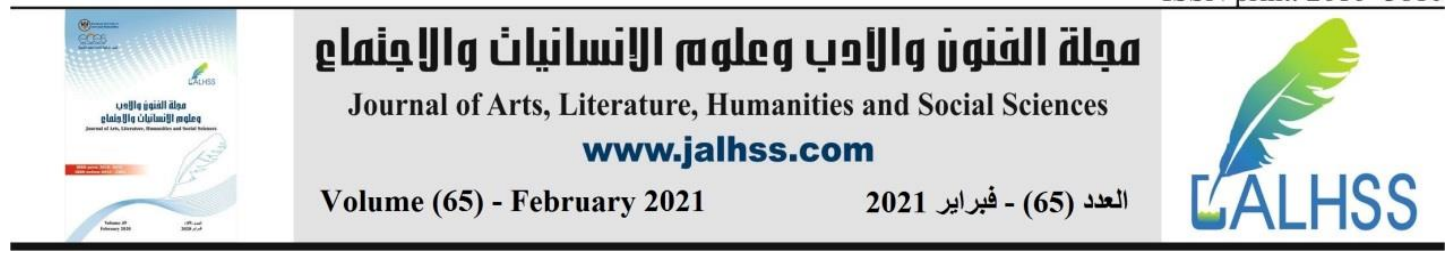

12. Recommendations

The researcher recommends:

-Providing educational leaders in Jordanian private universities with training courses to meet their training needs

- Planning the training courses of educational leaders based on the results of studies.

-Conducting researcher to explore the training needs of educational leaders in various types of educational institutions

-Employing technology for meeting the training needs of educational leaders

-Establishing centres by the Ministry of Higher Education \& Scientific Research and the Ministry of Education for meeting the training needs of educational leaders.

\section{References}

1. Al-Amery, A. (2020). Attitudes of the students at the institutes of fine arts in Iraq towards implementing active learning strategies in Arabic language courses and the associated challenges. Journal of Education and Practice, 11(13), 73-81, DOI: $10.7176 / \mathrm{JEP} / 11-13-08$

2. Al-Hawli, A. (2016). The Training Needs for the Principals of Governmental Schools in Gaza Governorates in the light of developing Human Resources. Published MA thesis. The Islamic University. Gaza. Palestine.

3. Allen J. (2003). A study of the professional development needs of Ohio principals in the area of educational technology. Published $\mathrm{PhD}$ dissertation. University of Cincinnati, Cincinnati.

4. Al-Omari, A. (2019). Professional Development of Educational Leaders in General Education Schools in the Kingdom of Saudi Arabia - Mohawk Governorate is a model. Arab Journal of Sciences \& Research Publishing, 2(22). DOI: 10.26389/AJSRP.E070618

5. Al-Zahrani, L. (2014). Training needs of the female principals of secondary schools for girls in Makkah from their perspective. Um Al-Qurrah University. Saudi Arabia.

6. Ashraah, A.; Al-Olaimat, A.; and Takash, H. (2015). Training Needs of Governmental Schools' Principals Hosting Kindergartens Classes: The Case for Jordan. International Education Studies. 8(8). 129-140, doi:10.5539/ies.v8n8p129

7. Brauckmann, S. (2008). The impact of school leadership on school results: Exploring the foundations of a relationship. The proceedings of the annual conference of the European School Heads Association (ESHA), Conditions of School Leadership in Europe, Copenhagen, Denmark.

8. Chris Sangster (2000): Planning and Organizing Personal and Professional Development. 1st edition. United Kingdom. Routledge, ISSN: 1351910930, 9781351910934

9. Fisher, A.; and Carlyon, T. (2014). School leaders growing leadership from within: A framework for the development of school leaders. Waikato Journal of Education. 19(2). 93-102

10. Glover, d. and Law, S. (1996). Managing professional development in education (Issues in Policy and Practice) Sussex: Psychology Press 


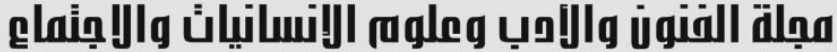 \\ Journal of Arts, Literature, Humanities and Social Sciences www.jalhss.com \\ Volume (65) - February 2021 \\ العدد (65) - فبراير 2021}

11. Hallinger, P., \& Snidvongs, K. (2008). Educating Leaders: Is There Anything to Learn from Business Management? Educational Management Administration and Leadership, 36(1), 9-39.

12. Hayat, A., Abdollahi, B., Zainabadi, H. R., \& Arasteh, H. R. (2015). A study of the professional development needs of Shiraz high schools' principals in the area of educational leadership. Journal of advances in medical education \& professionalism, 3(3), 99-104.

13. Hoy, W.K., and Miskel, C.G. (2008). Educational Administration: Theory, Research, and Practice. 8th ed. New York: McGraw-Hill.

14. Ibrahim N. Preparation and development of public secondary schools Principals in Kenya. International Journal of Humanities and Social Science. 2011; 1(9): 291.

15. Kegan, R. \& Lahey, L. (2000). Seven Discourses for Development. San Francisco: Jossey-Bass

16. Mathibe, I. (2007). The professional development of school principals. South African Journal of Education. 27(3)523-540 .

17. Ng, S.; and Szeto, S. (2015). Preparing school leaders: The professional development needs of newly appointed principals. Educational Management Administration \& Leadership. 44(4).p.540-557

18. Ng, S. (2013). Equipping Aspiring Principals for the Principalship in Hong Kong. Educational Management Administration \& Leadership..41(3). 272-288

19. Onuma, N. (2017). In-Service Training Needs of School Principals in Instructional Supervision for Teachers in Public Secondary Schools in Nigeria. International Journal of Humanities Social Sciences and Education (IJHSSE), 4(5), 91-98, http://dx.doi.org/10.20431/2349-0381.0405011

20. Pashiardis P, and Brauckmann S. (2009). Professional development needs of school principals. Commonwealth Education Partnerships. ; 3:120-4

21. Rayner, S, Gunter, H. \& Powers, S. (2002). Professional Development Needs for Leaders in Special Education, Journal of In-service Education, 28:1, 79-94, DOI: $10.1080 / 13674580200200172$

22. Salazar, S. (2007). The Professional Development Needs of Rural High School Principals: A Seven-state Study. The Rural Educator; 28(3): 20-7

23. Salehi, M., \& Farhang, A. (2019). On the adequacy of the experimental approach to construct validation: the case of advertising literacy. Heliyon, 5(5). Retrieved from: https://doi.org/10.1016/j.heliyon.2019.e01686

24. Sharaf, A. (2018). Training needs to raise the efficiency of school principals in light of contemporary administrative thought from their point of view. International Journal of Educational \& Psychological Studies (EPS). 3(2), 269-291

25. Terry, G. (1999). Principle s of management. In: Van der W esth uizen PC (ed.). Effective Educational Management, 9th impression. Pretoria: Kagiso.

26. Uğur, N.G. \& Koç., T. (2019). Leading and Teaching with Technology: School Principals' Perspective. International Journal of Educational Leadership and Management, 7(1), 42-71. DOI: 10.17583/ijelm.2018.3758

27. Walker, K, Carr-Stewart, S (2006) Beginning principals: Experiences and images of success. International Studies of Educational Administration, 34 (3): 17-36. 


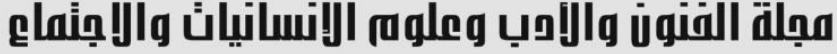 \\ Journal of Arts, Literature, Humanities and Social Sciences \\ www.jalhss.com \\ Volume (65) - February 2021 \\ العدد (65) - فبراير 2021}

\section{Appendix::}

\section{Appendix: The questionnaire}

Hello,

My name is Dr. Hatem Rateb Ameen Aljbour. I am working on a study titled (Training Needs of Educational Leaders in Jordanian Private Universities: Empirical Study). To have this study conducted, I need to collect data and analyse it. Thus, I need you to fill in the questionnaire. The data you will provide shall remain confidential

Through your answers, you contribute to developing the educational leaders working in Jordanian private universities professionally

Thank You

\section{Part one:}

Q.1. Are you a

$\square$ male or a $\square$ female?

Q.2. Do you work as a:

$\square$ head of department

Deputy head of department, $\square$ Faculty dean, or $\square$ Deputy faculty dean?

Q.3. Do you work in

$\square$ Al-Ahliyya Amman University, $\quad \square$ Petra University, $\square$ Isra University,

$\square$ Philadelphia University,

․ Al-Zaytoonah University,

or $\square$ Zarqa

University?

Please, fill in the tables below based on your view:

Part two: The administrative training needs

\begin{tabular}{|c|c|c|c|c|c|c|}
\hline No. & Statement & $\begin{array}{l}\text { Strongly } \\
\text { agree }\end{array}$ & Agree & Neutral & Disagree & \begin{tabular}{|l|} 
Strongly \\
disagree
\end{tabular} \\
\hline & There is a need for: & & & & & \\
\hline 1. & $\begin{array}{l}\text { developing the ability of } \\
\text { educational leaders to } \\
\text { identify the human and } \\
\text { financial resources that } \\
\text { are needed }\end{array}$ & & & & & \\
\hline 2. & $\begin{array}{lc}\text { developing the ability of } \\
\text { educational leaders to } \\
\text { document } & \text { students- } \\
\text { related data } & \end{array}$ & & & & & \\
\hline 3. & $\begin{array}{l}\text { developing the ability of } \\
\text { educational leaders to } \\
\text { set plans for } \\
\text { maintaining } \\
\text { facilities of the } \\
\text { university }\end{array}$ & & & & & \\
\hline
\end{tabular}




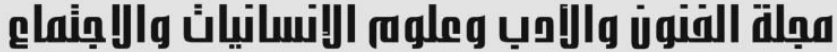

Journal of Arts, Literature, Humanities and Social Sciences

www.jalhss.com

Volume (65) - February 2021

العدد (65) - فبراير 2021

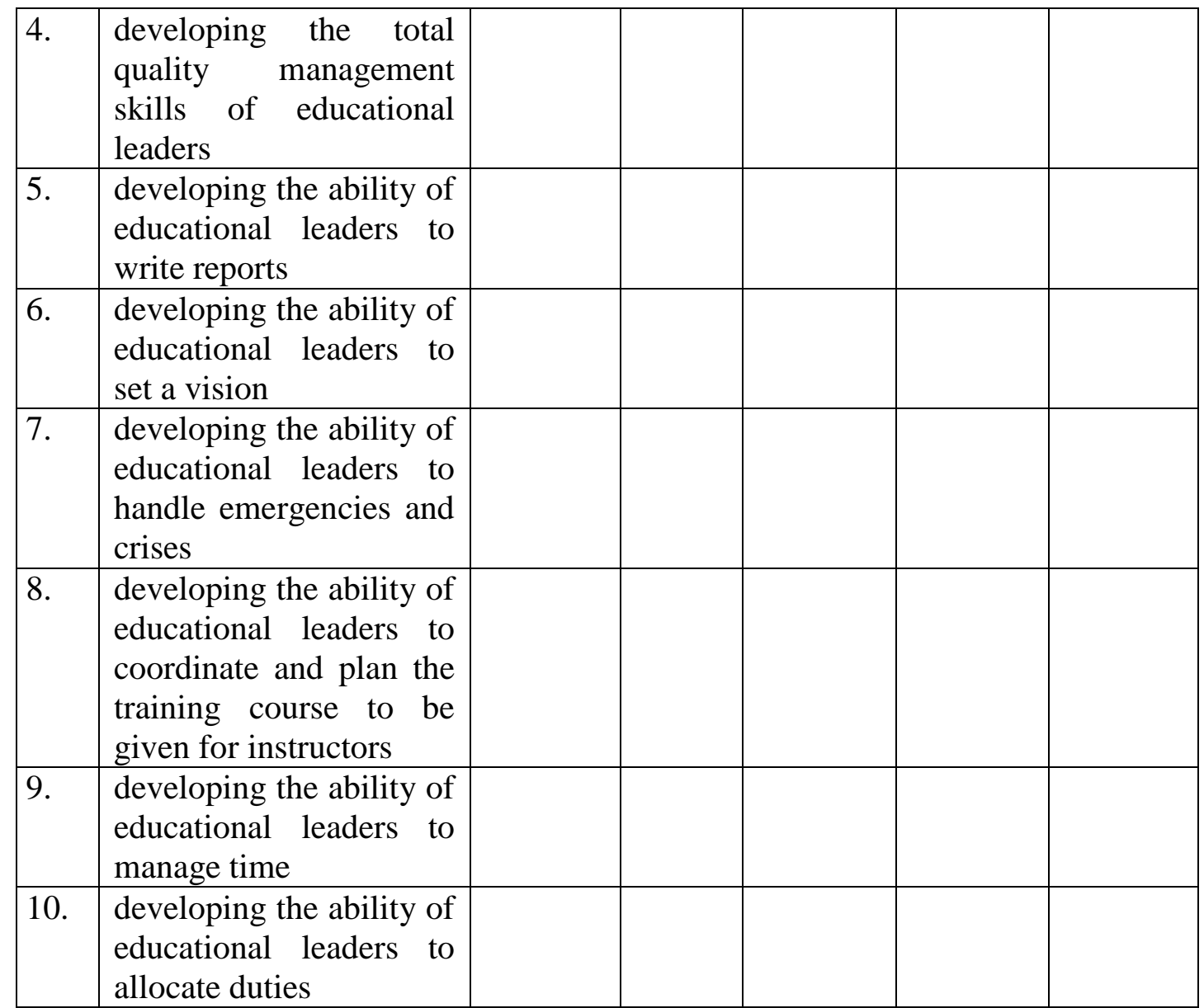

*Source: Al-Hawli (2016) and Sharaf (2018).

Part three: The technical training needs

\begin{tabular}{|l|l|l|l|l|l|l|}
\hline No. & Statement & $\begin{array}{l}\text { Strongly } \\
\text { agree }\end{array}$ & Agree & Neutral & Disagree & $\begin{array}{l}\text { Strongly } \\
\text { disagree }\end{array}$ \\
\hline 1. & $\begin{array}{l}\text { There is a need for: } \\
\text { developing the ability of } \\
\text { educational leaders to } \\
\text { analyse the content of } \\
\text { curricula }\end{array}$ & & & & & \\
\hline 2. & $\begin{array}{l}\text { Promoting knowledge } \\
\text { among educational } \\
\text { leaders about the way of } \\
\text { developing } \\
\text { instructors' } \\
\text { competencies }\end{array}$ & $\begin{array}{l}\text { developing the ability of } \\
\text { educational leaders to } \\
\text { use modern supervising } \\
\text { methods }\end{array}$ & & & & \\
\hline 3. & & & & & \\
\hline
\end{tabular}




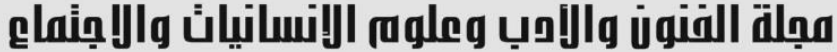

Journal of Arts, Literature, Humanities and Social Sciences

www.jalhss.com

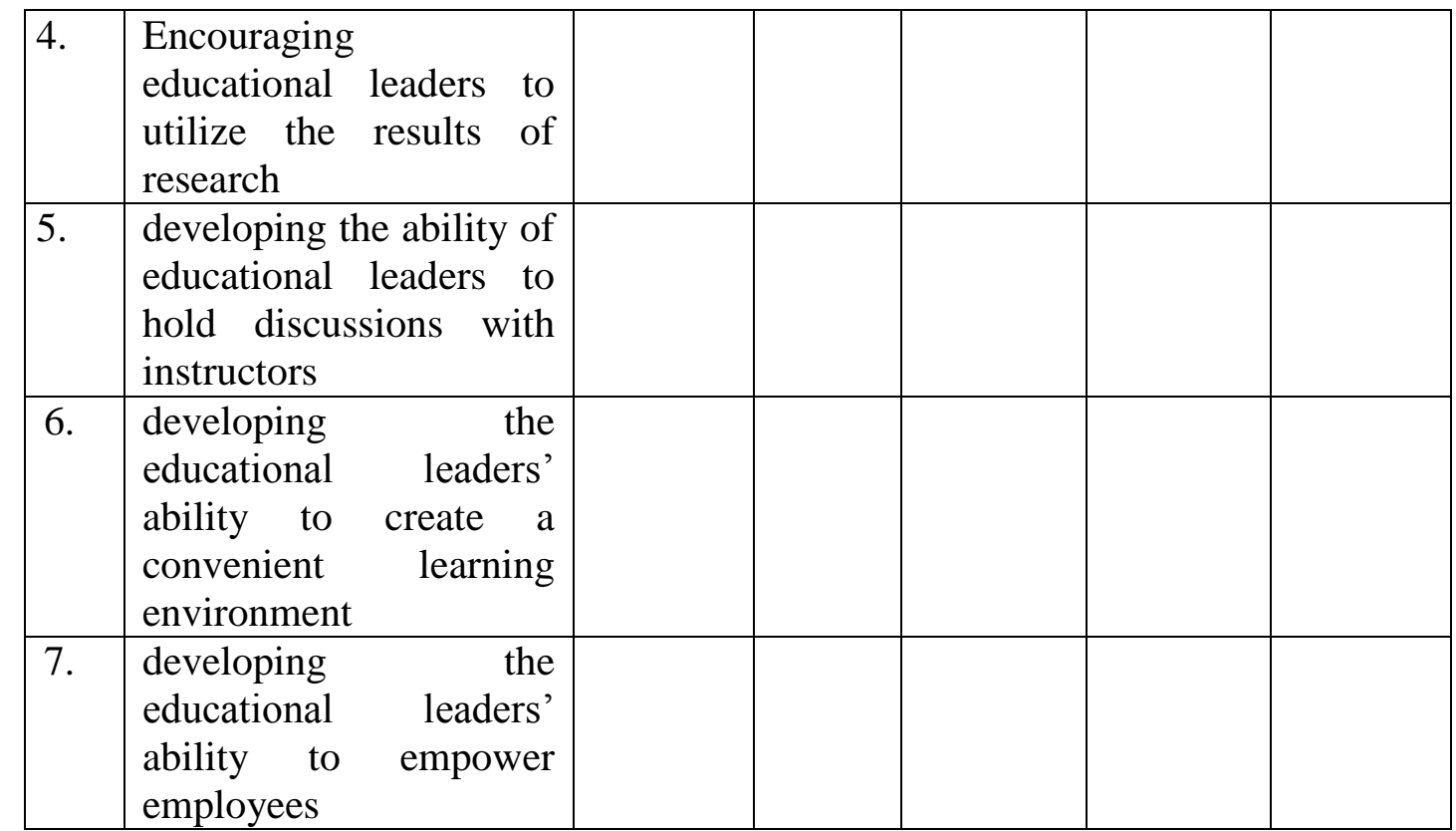

*Source: Al-Hawli (2016) and Sharaf (2018)

Part four: The social training needs

\begin{tabular}{|c|c|c|c|c|c|c|}
\hline No. & Statement & $\begin{array}{l}\text { Strongly } \\
\text { agree }\end{array}$ & Agree & Neutral & Disagree & $\begin{array}{l}\text { Strongly } \\
\text { disagree }\end{array}$ \\
\hline & There is a need for: & & & & & \\
\hline 1. & $\begin{array}{l}\text { developing the ability } \\
\text { of the educational } \\
\text { leaders to solve the } \\
\text { social problems } \\
\text { between students }\end{array}$ & & & & & \\
\hline 2. & $\begin{array}{l}\text { developing the ability } \\
\text { of the educational } \\
\text { leaders to solve the } \\
\text { social problems } \\
\text { between instructors }\end{array}$ & & & & & \\
\hline 3. & $\begin{array}{l}\text { encouraging the } \\
\text { educational leaders to } \\
\text { attend the social } \\
\text { celebrations and } \\
\text { events of employees }\end{array}$ & & & & & \\
\hline 4. & $\begin{array}{l}\text { encouraging the } \\
\text { educational leaders at } \\
\text { the university to take } \\
\text { the instructors' needs } \\
\text { and interests into } \\
\text { consideration }\end{array}$ & & & & & \\
\hline 5. & encouraging the & & & & & \\
\hline
\end{tabular}




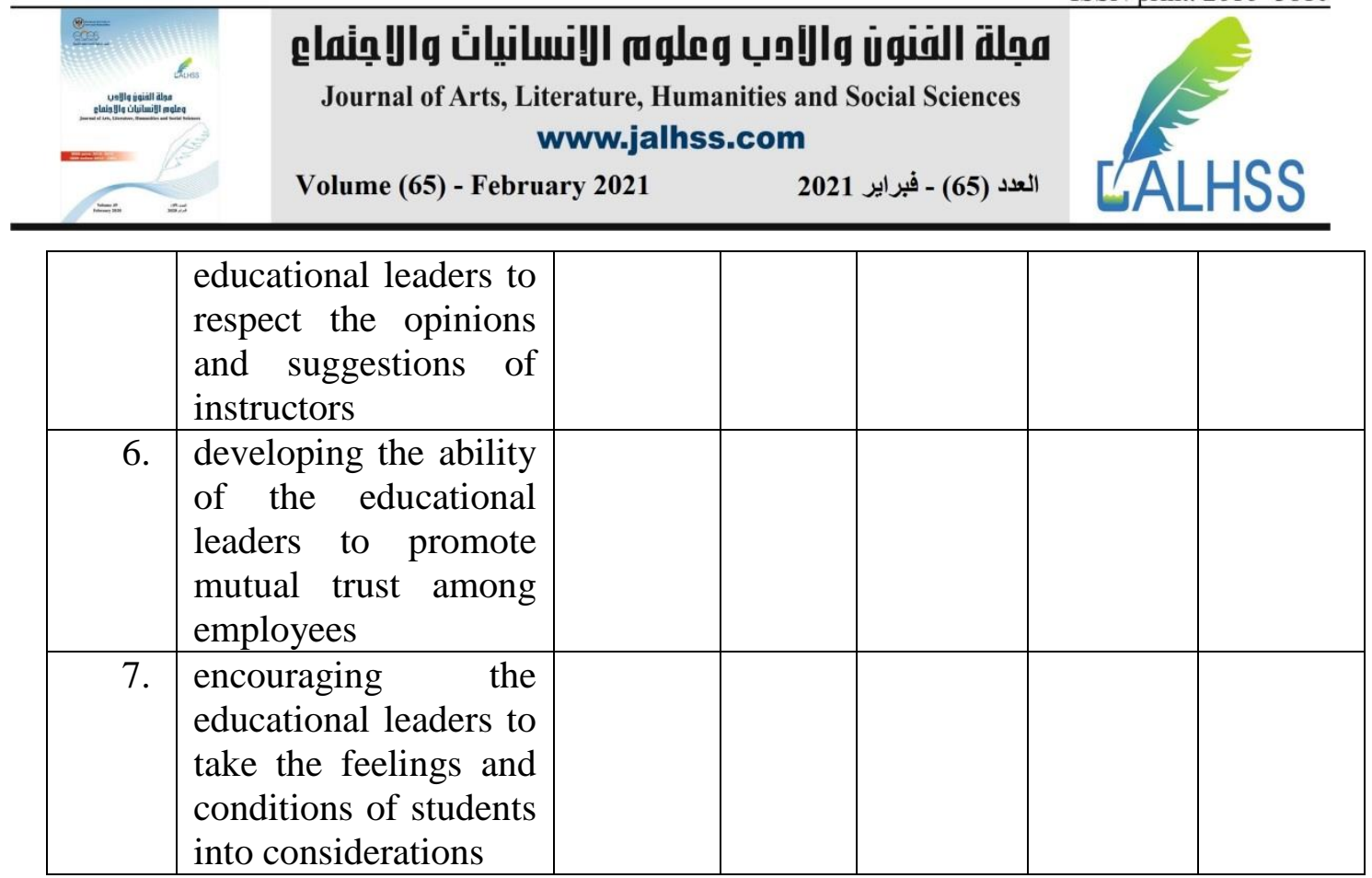

*Source: Al-Hawli (2016)

Part five: The IT-related training needs

\begin{tabular}{|c|c|c|c|c|c|c|}
\hline No. & Statement & $\begin{array}{l}\text { Strongly } \\
\text { agree }\end{array}$ & Agree & Neutral & Disagree & $\begin{array}{l}\text { Strongly } \\
\text { disagree }\end{array}$ \\
\hline & There is a need for:: & & & & & \\
\hline 1. & $\begin{array}{l}\text { developing the ability of } \\
\text { the educational leaders } \\
\text { to use Microsoft Office } \\
\text { programs }\end{array}$ & & & & & \\
\hline 2. & $\begin{array}{l}\text { developing the ability of } \\
\text { the educational leaders } \\
\text { to use e-mails }\end{array}$ & & & & & \\
\hline 3. & $\begin{array}{l}\text { developing the ability of } \\
\text { the educational leaders } \\
\text { to use social media (e.g. } \\
\text { Twitter, Facebook, and } \\
\text { etc..) }\end{array}$ & & & & & \\
\hline 4. & $\begin{array}{l}\text { developing the ability of } \\
\text { the educational leaders } \\
\text { to research through } \\
\text { using the web }\end{array}$ & & & & & \\
\hline 5. & $\begin{array}{l}\text { developing the ability of } \\
\text { the educational leaders } \\
\text { to use the e-learning } \\
\text { platform }\end{array}$ & & & & & \\
\hline 6. & $\begin{array}{l}\text { developing the ability } \\
\text { of the educational } \\
\text { leaders to develop, and } \\
\text { implement r policies } \\
\text { related to using }\end{array}$ & & & & & \\
\hline
\end{tabular}




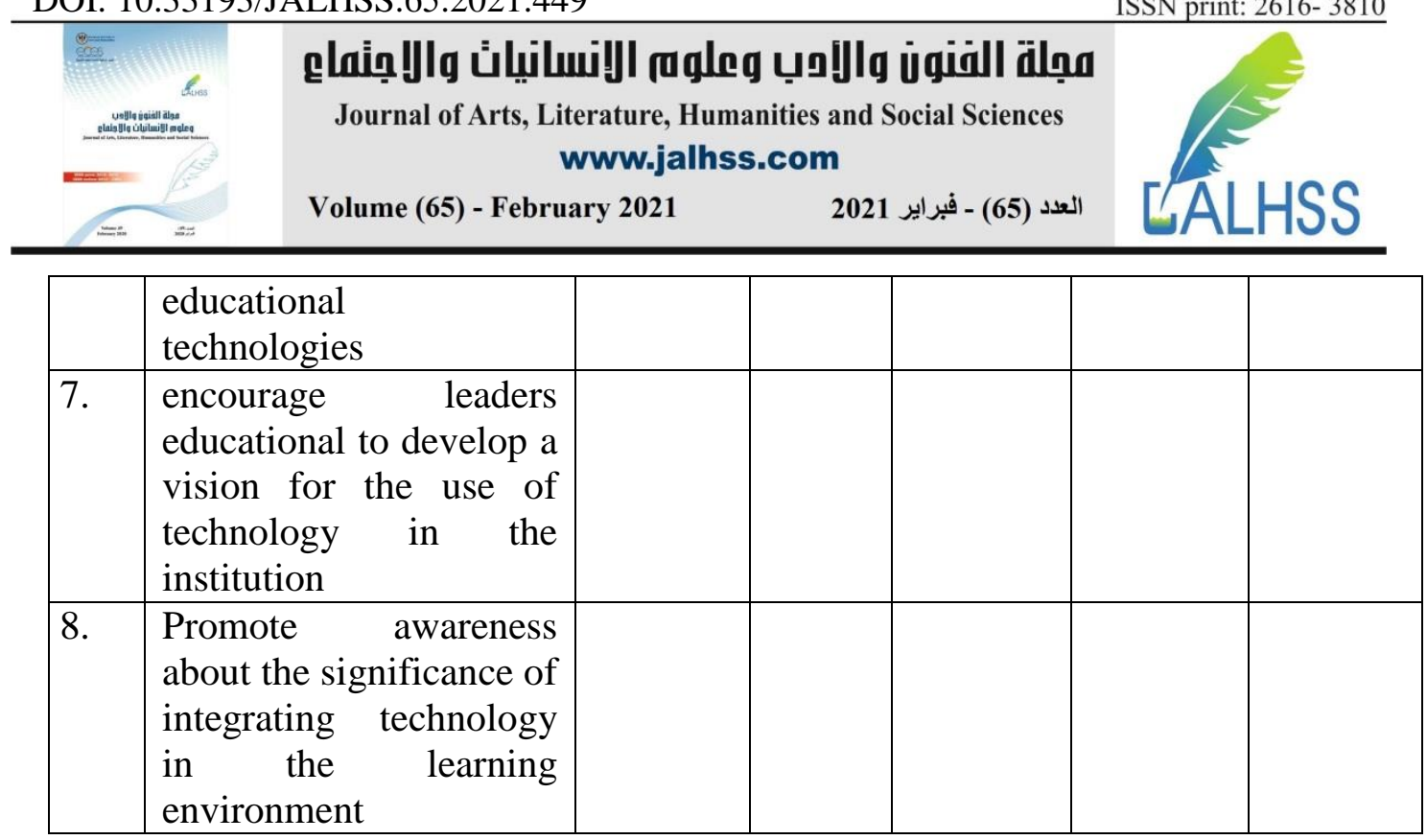

*Source: Al-Hawli (2016) 